\title{
OUR CLOCK MOVES AT A DIFFERENT PACE: THE TIMESCAPES OF IDENTITY IN ESTONIAN RURAL TOURISM ${ }^{1}$
}

\author{
Maarja Kaaristo, Risto Järv
}

\begin{abstract}
One of the effects and results of tourism is that it marks our sense of time, differentiating the extraordinary and 'heightened' time and the time of the mundane. An important role in this is played by the hosts - in the case of rural tourism by the farm owners and tour guides. The tourism farmers and tour guides act as mediators of the temporal experience, therefore creating and providing various timescapes for their guests. An altered perception of time, a distinctive temporal experience of place is offered to guests as a specific and special characteristic and a counterbalance to the rush of everyday life in the local identity of two rural border regions. Some meaningful and meaning-forming, interconnected and sometimes opposite notions of temporality are analysed as narrated by tourism farmers and tour guides in two very popular tourism regions in Estonia: Hiiumaa Island and Võru County. The ways in which these hosts (re)construct and perceive temporality are identified and presented and some distinctive elements of those rural timescapes are considered.
\end{abstract}

Keywords: Estonia, identity, rurality, rural tourism, temporality, timescape

Tourism can be defined as an activity of temporary leisure (sometimes contrasted with 'work'), a sensation of place away (from home), and an activity the purpose of which is to experience change (Smith 1989 [1977]: 1). Thus, starting from the very first definitions in the field of anthropological tourism studies, the temporal aspect has been one of the defining elements of tourism: it has been described as the "temporary movement of people" (Mathieson \& Wall 1982: 1) and the tourists' periods of stay in their destination are usually "of a short-term and temporary nature" (Urry 2000a: 3).

Tim Edensor has suggested that "one of the effects of tourism is to mark out time, that of the extraordinary from the time of the mundane, a period of relaxation and play which marks release from work and duty" (Edensor 2000: 325). These temporal conceptions of tourism involve the idea of a temporary opportunity to reveal a more 'true' self (that can temporarily put aside the everyday mask that is usually put on to cope with the stresses and strains of 
everyday life), the desire to realise a different, sometimes hidden side of one's personality (ibid.). A different perception of time is also an important theme in many folktales plots (Kaasik 2008), and a similar differentiation can also be detected in the ways of experiencing the "touristic" trips undertaken (Järv 2010). Or, as James Buzard (1993: 102-103) has put it rather poetically: "Travel [---] an ameliorative vacation [---] promises us a time or imaginary space out of ordinary life for the free realization of our otherwise thwarted potential."

The time of tourism (/the tourist) can be viewed as a continuum of various meaningful relationships among people, objects, and space continually being made in and through the lived experience both by guests (tourists) and hosts (people working in the tourism industry). In this article we will focus on the notions of time and temporality as an aspect of local identity within the field of rural tourism in Estonia, and look at how the concept of time has been theorised in the context of tourism research. The second half of the article focuses on the notion of timescapes, complex temporal environments where the time is experienced, negotiated and imagined by the tourism farmers and tour guides. We will dwell upon some of the time practices that they mediate and provide (among other experiences) to their guests. They share with their guests a somewhat altered, different perception of time, a distinctive temporal experience of place as a specific and special characteristic of those two rural regions. Our main goal is to view some of the strategies that people working in the tourism industry use to mediate these living environment timescapes to their guests.

\section{FIELD SITES, EMPIRICAL SOURCES AND METHODOLOGY}

We focus on two Estonian border regions: Hiiu County (Hiiumaa Island off the coast of western Estonia) and Võru County (in South Estonia), two very popular domestic tourism destinations where people have a somewhat stronger sense of local identity due to some unique historical and cultural characteristics. These include, for example, the clearly distinctive local dialect spoken quite widely; the geographical location (Hiiumaa's position as an island and the location of Võru County at the other end of the country when looking from the capital, Tallinn); the natural environment (a hilly landscape with many lakes in Võru County and a landscape dominated by junipers characteristic of Hiiumaa), etc. (On some aspects of Võru (võro in local dialect) identity see, for example, Koreinik \& Rahman 2000; Ehala 2007; Koreinik 2011; and on Hiiu identity: Uljas 2001; Uljas \& Post 2002; Lindroos 2009.)

Empirical data on Võrumaa were gathered by Maarja Kaaristo during three field trips to Rõuge, Haanja and Võru municipalities in July and September 


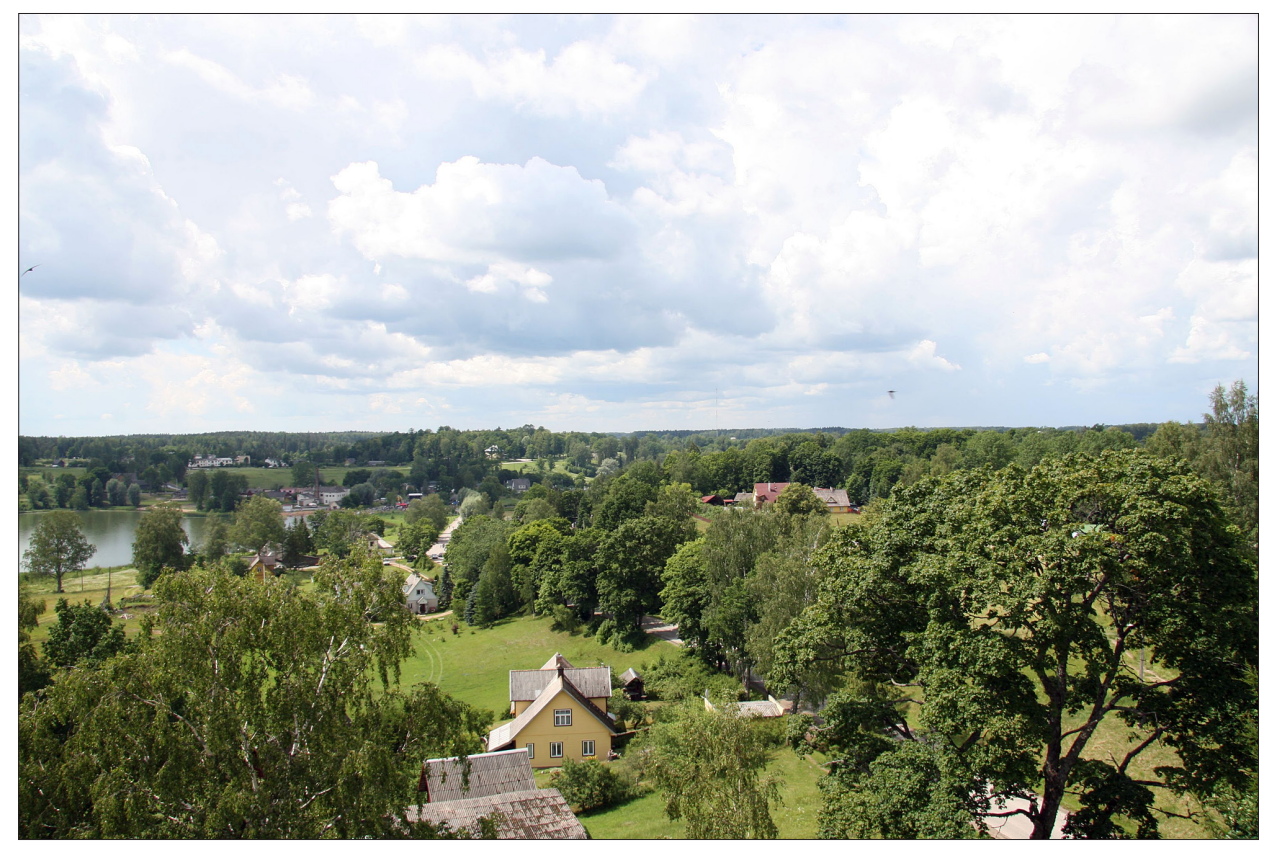

Figure 1. A View of Rõuge. Photo by Maarja Kaaristo 2008.

2008 and June 2010. During her first field trip, the goal was mainly to study the issues of locality and identity (on the basis of a questionnaire devised by professor Art Leete), and to conduct interviews with local business people and representatives of the local municipality, tourism officials and other people living in the area. The interviews covered a wide range of topics, such as people's attitudes toward their rural living environment, use of local dialect, etc. During this fieldwork Kaaristo's attention was directed towards the general topic of rural tourism by her colleague Ester Võsu, with whom she undertook a second field trip in September, this time focusing specifically on rural tourism. Kaaristo and Võsu visited several tourism farms in the area and recorded interviews with their owners using another questionnaire that concentrated on the tourism farmers' perceptions of their living environment (some results of this fieldwork have been published in Võsu \& Kaaristo 2009; Võsu \& Kaaristo 2010). These semi-structured in-depth interviews held with nine tourism farmers on their farms, which form the main empirical basis of the information on Võru County, concentrated on the issues of tourism farming (the farmers' motivation: how and why they had chosen this lifestyle, their general opinions about the tourism situation in Võrumaa and Estonia, their guests and what sort of services were provided for them, and questions about local life in general (culture and the 
environment)). In 2010, the focus of fieldwork in Võru municipality continued to be on hosts working in the tourism sphere (Võru Tourism Information Centre); in general, two main methods were adopted - semi-structured interviews and (participant) observation.

Material on Hiiumaa Island was gathered by Risto Järv in October 2009, July 2010 and August 2011. During the two first field trips research focused on how tour guides in Hiiumaa make use of and mediate folklore, and Järv also interviewed several employees of local museums. Risto Järv's questionnaire for the semi-structured interviews was inspired by Melika Kindel's MA thesis (2005) about local traditions and tourism in Lahemaa National Park. Altogether, 17 interviews were conducted, some of them together with a colleague Reeli Reinaus. In these interviews the following topics were discussed: folkloristic narratives in tour guides' narratives and their reception by the tourists; the sources of those narratives (books, the Internet, family oral history) and their proportion in the guides' repertoires; terminology in the traditional material; how the hiiu way of life or identity is constructed in the guides' narratives (local dialect, local sense of humour, relations with the neighbouring Saaremaa Island). After the general idea for this article had been conceived, in August 2011 Järv concentrated on tourism farmers and issues of their identity. All of our informants have agreed that we use their real first names and ages when quoting them.

To some extent, the issue of self-reflexivity must also be considered in both our fieldwork studies. Kaaristo regards herself as a 'local' in Võru County, as she was born there into a vorro ${ }^{2}$ dialect speaking family, and often visits her parents and friends, which allows her to identify herself as a vorroke despite having lived elsewhere for the past 12 years. Järv also feels strong emotional ties to Hiiumaa through his grandfather, who was born and lived on the island until his adolescence. The reason for Järv's first longer 'exploration' of this island in 2008 was a search for his roots, after which he has conducted folkloristic interviews there for at least a week each year, trying to experience local life not just as a visitor but also as a researcher. Although we do not believe that this has provided us with the special advantages of "cultural competence" (Ruotsala 2001: 118), it has certainly had some impact on the course of our fieldwork, the ways of communication and relations with local people, and in a broader sense, on our choice of topics related to Võro and Hiiu identities in general. It must also be noted that while the question of time-perception and temporality was initially explicitly not addressed in either of our questionnaires of 2008-2010, the subject rose rather prominently in discussions with most of the farmers and tour guides. 


\section{TEMPORALITY OF TOURISM}

In his article "Tourism: The Sacred Journey" anthropologist Nelson Graburn argues that "a major characteristic of our conception of tourism is that it is not work, but a part of the recent invention, re-creation, which is supposed to renew us for the workday world" (1989 [1977]: 22, original emphasis). In this sense tourism is something inherently temporary, short-term and extraordinary, something that happens only once in a while and is clearly distinguishable from non-tourism, i.e., everyday life.

According to Graburn, this division of work and leisure, something that enables tourism overall, can structure our perception of time, which is, as he points out, very similar to that of the ritual, analysed and conceptualised by a lengthy line of theoreticians. There is a long tradition in anthropology of structural examination of events and institutions as markers of the passage of (natural and social) time, which is rooted partly in Émile Durkheim's (2001 [1912]) notions of the sacred and the profane: according to Durkheim, "religious beliefs, whether simple or complex, present a common quality: they presuppose a classification of things - the real or ideal things that men represent for themselves - into two classes, two opposite kinds, generally designated by two distinct terms effectively translated by the words profane and sacred" (Durkheim 2001 [1912]: 36).

Henri Hubert and Marcel Mauss (1964 [1898]), when analysing rituals of sacrifice, talk about sacralisation that elevates the participants to another state of being, and about the process of desacralisation that follows it, when everything returns to the regular state. Edmund Leach in his essay from 1955 "Time and False Noses" (Leach 2004: 132-136) suggests that the regular occurrence of sacred-profane alternations marks important periods of social life and in addition to that provides a measure of the passage of time. A ritual puts a stop to normal and profane time, and creates abnormal or sacred time; the end of the ritual signifies reintegration with the normal and mundane. Through the experience of this ritual structure, people become adults (initiation, rites of passage), are welcomed into this world or sent to the next (birth or funeral rituals), or move on to the next year (new year festivals), etc. This kind of (temporal) structure of the sacred and the profane in the Estonian folk calendar has been studied by folklorist Mall Hiiemäe (1998). All in all, these types of rituals function as markers in time and the total flow of time has a pattern: according to Graburn there is a fundamental contrast between the ordinary/compulsory (quite often work) state spent at home and the non-ordinary/voluntary sacred "away from home" state, and a stream of alternating contrasts provides meaningful events that measure the passage of time. Therefore, one of the effects 
of tourism is to mark time, to differentiate the extraordinary and 'heightened' time and the time of the mundane.

During this period of tourism, one is temporarily freed from many of the norms and limitations of everyday life and, following Graburn, tourism can thus be compared with the idea of the liminal time period. This notion was first coined by Arnold Van Gennep in his Rites of Passage (2004 [1909]), which describes the rites of transition in traditional tribal societies that consist of preliminal, liminal and postliminal states. This was later followed up by Victor Turner (1967: 93-111; 2008 [1969]), who expanded the notion of liminality as an "interstructural situation" (Turner 1967: 93). During a rite of passage, an individual is in the liminal phase, "neither here nor there" (Turner 2008 [1969]: 95), in a state in which the structuring properties of the 'normal' no longer apply, and which is characterised by a perception that time beyond a certain boundary is different from that of the everyday.

Graburn's (1988) tourism is a liminal (or "liminoid", as Turner himself later on suggested for other phenomena resembling liminal rituals, yet which differ from them by free will and optionality in the choice of actions (Turner 1982: 20-60)) kind of "anti-structural" phenomenon, where the usual everyday routine is turned over and the norms no longer apply. While travelling, the tourist inhabits a state between the two worlds full of endless possibilities, belonging fully to neither (Järv 2010: 283), doing and believing in things they usually might not in everyday situations, as one of the tour guides explains:

They [the tourists] come here to spend their holidays; they want to get away from their usual environment. So we go to Tahkuna [peninsula], there is a Kandle pine tree by the side of the road. This pine tree takes all your illnesses away. So I talk about it and all of them want to stop there [---] and we cannot deny it to them. I wouldn't say they're exactly gullible, but they believe everything I tell them about it. (Tiiu, b. 1958, Hiiumaa)

This is a common situation in which the tourist chooses to adhere to new norms or structures to his or her liking: new norms of behaviour (e.g. making new acquaintances more easily), new norms of clothing (scantier, more casual, etc.), interests (visiting 'the sights', museums and churches even if one might never do so back at home), daily routine (waking up late, staying up all night), establishing him/herself as a part of new social networks, which cease to exist or fade when back at home, and so on. During this 'sacred journey' of tourism, the passage of time is experienced in a different manner, and the time spent travelling can seem more 'real' than 'real life', at least quality-wise, as one of the tourism farmers said: 


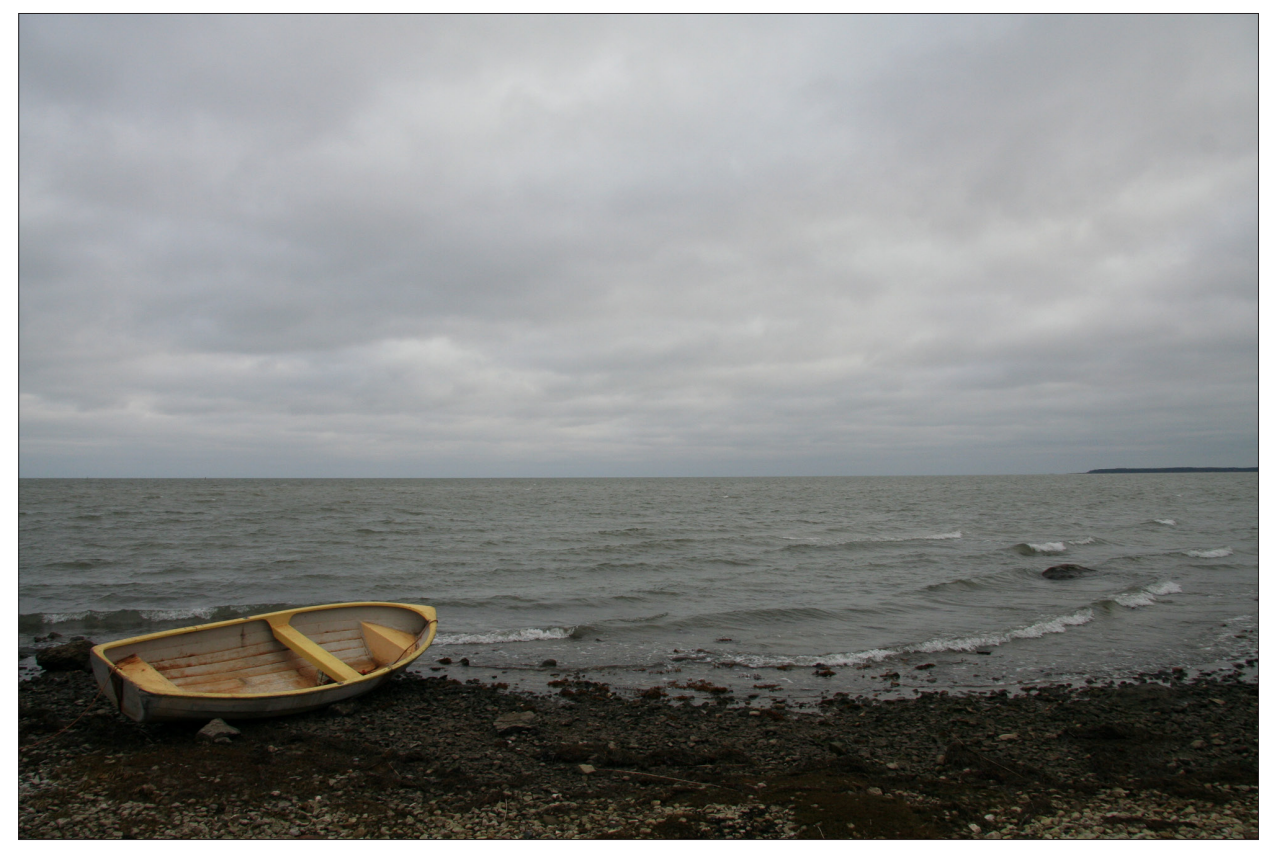

Figure 2. For the tourist the water border can mark a shift in timescape where one can be freed from everyday problems. A fishing boat near Heltermaa harbour. Photo by Elo Järv 2009.

You leave everything behind when you step on the ferry: all your troubles and obligations and ... everything. You are somewhere ... I don't know where, in another realm, perhaps. And I think it's the water's fault, this water in between. This water, this wide water border changes us inwardly and frees us from all our everyday problems. (Kalle, b. 1956, Hiiumaa)

Holidays spent 'somewhere else' can be described as, “I was really living, living it up ... I've never felt so 'alive' in contrast to the daily humdrum. Thus, holidays (holy, sacred days, now celebrated by travelling away from home) are what make 'life worth living' as though ordinary life is not life or at least not the kind of life worth living." (Graburn 1989: 26) These notions all incorporate ideas concerned with "letting your hair down", "getting away from it all", and "letting go" - the associations which sometimes assert the need to perform acts of a different nature compared with everyday life (Edensor 2000: 325).

However, one might say that according to this schema, time could be seen essentially as unidirectional, linear, continuous flow, with sequences of events, 'heightened', but nevertheless kind of 'strung up' on a line that extends from the past into the future, just as Barbara Adam (2005: 506) criticises the "tra- 
ditional Western" notion of time in anthropology. So it is quite clear that this 'time of tourism' needs more elaboration and our aim is to try to look at it as a continuum of various meaningful relations among people, objects, and space, which are constantly reinvented and made in and during lived experiences. As Nancy Munn (1992: 116) writes, human temporality is

a symbolic process continually being produced in everyday practices. People are in a socio-cultural time of multiple dimensions (sequencing, timing, past-present-future relations, etc.) that they are forming in their 'projects'. In any given instance, particular temporal dimensions may be foci of attention or only tacitly known. Either way, these dimensions are lived or apprehended concretely via the various meaningful connectivities among persons, objects, and space continually being made in and through the everyday world.

According to Leach (1976: 34), in the biological sense we experience the passage of time in a continuous way, supported by the fact that we get older "all the time". However, this experience, this continuum has to be divided into measurable segments of time like seconds, minutes, hours, and so on. "Each segment has duration, but notionally the intervals between the segments, like the bar lines on a musical score, have no duration. However, when we come to convert this notional time into social time by acting it out, each 'interval of no duration' itself takes up time." (Leach 1976: 34) We move from one present to another without having to break through any chronological barriers that might be supposed to separate each present from the next in line. The features that were previously identified as serving the segmenting function - rites, feasts, and ceremonies, or, in our case, the touristic journey - are all integral elements of temporality (just boundary markers such as walls or fences to the landscape) (Ingold 2000: 196). In practice, of course, there are no strict separations or boundaries between these different "segments" of time and "there is no direction in which flux or process is moving, and there is no one river of time that flows" (Hodges 2008: 415, original emphasis). The passage on a ship that takes you from mainland Estonia to the island of Hiiumaa is one of the boundaries or markers that denotes the passage of time (the only ways to get to the island are either by sea, which most of the locals and visitors use, or by aeroplane, which is used less frequently as it is more expensive; there are no bridges or other connections). While on board a ferry, you cannot decide on the pace of your movement yourself, you have to follow (and adjust to) the pace of the ferry. You experience those boundaries (passage on the ferry) as integral elements of temporality, not as something that is somehow segmenting your personal time into clearly distinctive parts. 
The time of the tourist is definitely not a linear unidirectional river; nor is it easy to separate 'tourism' from 'work'. Leisure is not a field that can be clearly delimited from working time and today we cannot juxtapose work and leisure (or tourism) antagonistically as the boundaries between work and leisure time increasingly wear away and blur. Where should we position answering workrelated e-mails while on vacation or taking a day off to go sightseeing during a work-related trip? Laptop work combined with the spreading availability of the (wireless) Internet is quite a new phenomenon that clearly has had and will have an immense influence on the ways we perceive work and leisure. Should working from a tourism farm (most of the visited farms had excellent wireless internet connections) be classified as work or leisure or something in between? And where should we draw the line? Should there be a line at all? In addition, it should be noted that the nature of 'work' largely depends on the particular (tourist) context. This means that some activities, which for some people (for example tourism farmers) are everyday chores, can in special settings become interesting leisure or pastime activities for others:

And a Swedish army major stayed here for twelve days. He milked the cow and everything ... [---] We didn't think of offering him this opportunity, he insisted on it. So when I went to the cowshed in the morning to clean it up a bit half an hour before the time we had agreed on, he was already there. He was afraid that maybe I would milk the cow myself and wouldn't let him! (Margit, b. 1968, Võrumaa)

This also means that sometimes the amount and nature of the farm work can actually follow the seasonality of the tourists visiting the place. One of the guides at a farm museum explained how they just let the guests "perform" some farm works despite the fact that it had actually been done already and the season was long over (for example, haymaking).

The seasonality of the tourists' visits also turns the pace of life upside down for the tourism farmers and the tour guides, at least compared to other people living in the area. All of them explained how their rhythm of life differed greatly from the others on many levels. For one, summer is the busiest time and therefore they can almost never take a vacation then (if they do go on holiday, they usually do so during winter or late autumn). And, of course, this time that might seem a time for relaxation for tourists or for people living on the island, from the perspective of those working in the tourism industry it is the most hectic time of the year:

...summer is so intense, one would think we live here on the island in our slow rhythm, what can there be, it's boring. But actually the summer is so intense, much more so than in the cities; generally the locals here 
look forward to the autumn to get some peace again. But of course we have lots of change here in our year. The summers are a big change for us. (Tiiu, b. 1966, Hiiumaa)

Nelson Graburn (2001) has also added a distinction between the high and low points in the time of tourism. He asserts that the "sacral phase" of the experience is by no means monolithic. Graburn also implies that each experience is different for every tourist, making each one "personally negotiated". The most obvious example of this is that the pace of time, and how we interpret and perceive it, may vary, depending very much on the particular (tourism) situation. When discussing the changing nature of the relationship between work and leisure, the German researcher Karlheinz Wöhler (2006: 188) concludes that "the dissolution of boundaries means that time has lost its place and place has lost its time", and it is quite clear that this de-bounding of place and time modifies work and leisure and neither of the spheres can be seen as 'pure', as all these different notions of work and leisure overlap and blur.

\section{EXPRESSING THE IDENTITIES DWELLING IN TIMESCAPES IN VÕRUMAA AND HIIUMAA}

Two guys from Männamaa [a village on Hiiumaa Island] were walking in Kaigutsi village during the first republic [1920s-1930s] and saw a pocket watch lying on the road in the sand. They didn't know what a pocket watch was. They examined it and discussed it there and one of them said: "I know what it is!"

- "What is it then?" the other one asked.

- "You know, this is the eye of envy and evil."

And the other one took a stone, he was the more lively one, and smashed it. But the world was saved, wasn't it? (Kalle, b. 1957, Hiiumaa)

Although recent developments in anthropology suggest that we move away from the term 'identity', which has been called a "heavily burdened, deeply ambiguous term" (Brubaker \& Cooper 2000: 8), it is nevertheless still admitted that "the idea that everyone is the same and there are no distinctive differences in meaning and style is ridiculous; there are. But identifying them and explaining them is the challenge" (Rabinow et al. 2008: 108). Margaret Somers has suggested reinventing the concept of identity by using the notion of narration since a "way to avoid the hazards of rigidifying aspects of identity into a misleading categorical entity is to incorporate into the core conception of identity 
the categorically destabilizing dimensions of time, space, and relationality" (Somers 1994: 606, original emphasis).

Therefore, we will attempt to track down and explain some of those "distinctive differences" as exemplified by the perception of temporality narrated by tourism farmers and tour guides in Võrumaa and Hiiumaa. We will not be looking at identity as some sort of "rooted body that grows, lives, dies, and so on", but instead at the identification processes as "constructed and disputed historicities, sites of displacement, interference, and interaction" (Clifford 1997: 25), which are "dynamic and dialogic, found in the constellations of a huge cultural matrix of images, ideas, spaces, things, discourses and practices" (Edensor 2002: 17). Those matrices are formed and transformed by certain groups and individuals, who produce meanings and connotations, therefore sometimes creating "symbolic communities" (Solomos 2001: 203), in our case we could say, temporal communities.

We view identification not as a "return to roots but a coming-to-terms-with our 'routes"' (Hall 2003: 4) and therefore try to move away from the analyses that tend to be more weighted towards 'heritage' and the 'common past' rather than the 'common future' or even 'common present' (Roche 2001: 75). The interviewed people who work in rural tourism do not necessarily search for the temporal golden past or pastoral idyll; their appreciation of their temporal environments is based on a conscious negotiation of different aspects of their living environments, and they bring forth the ones that they themselves or their guests appreciate, and, therefore, certain new rural identities are formed and forged. Or, putting it in a different way, "identities, understandings of experience, and foundations of knowledge are fractured from the start" and we should aim to "work with, rather than deny, the collisions and crises between and within all the oppositional predicates inhering in the articulation and elaboration of the emancipatory promise" (D'Cruz 2008: 5). Tourism does not exist in isolation but is heavily intertwined with the aforementioned elements of identification, the (re)presentations of which are continuously being (re)produced and consumed by various actors (Pritchard 2000).

Since human temporality is a symbolic process "continually being produced in everyday practices" (Munn 1992: 116), time and temporality are constantly being (re)produced and interpreted by the tourism farmers and tour guides for whom the sense of time seems to be largely place specific, forming a part of their local identity. We will use the notion of timescape to look at the temporal aspect of rural tourism in Võru and Hiiu counties. As both authors' fieldwork has shown, tourism farmers and tour guides find the different temporal quality of the experiences they provide and mediate very important, therefore creating various timescapes for their guests. According to Barbara Adam (2004: 143), a 
timescape is a cluster of temporal relations and features in certain spaces and contexts, related to particular practices of "transcendence and transformation". The notion of '-scape' indicates that time is inseparable from space and matter; it gives scale, perspective and context. All in all, a timescape is a broad perspective on the complex temporalities of the world around us, a temporal environment of memories, experience and imagination. Timescapes "emphasise their rhythmicities, their timings and tempos, their changes and contingencies. A timescape perspective stresses the temporal features of living. Through timescapes, contextual temporal practices become tangible. Timescapes are thus the embodiment of practical approaches to time" (Adam 1998: 10).

It is in this context of the deep-felt connection between time and place that a tour guide, coming from generations of Hiiumaa islanders, is positioning herself and constructing her own expertise for mediating this island to guests:

$\ldots$ and when I am narrating them the lore of my father or grandfather or someone else, I tell them that it's like 'my father says' - because I am a hiidlane $e^{3}$ myself, I can tell them the stories of my great-grandfather if I like, for example, I can tell them that my great-grandfather was a very good brewer in that village or estate, and I am very proud that I have this long family lore of 300 years, that I have all those ancestors. I am from this island. Because usually the guests are happy when they meet someone local. This is my strong suit and the source of my pride. (Helgi, b. 1956, Hiiumaa)

Filipa Wunderlich has argued that "places are temporal milieus within which repetitive everyday activities, spatial patterns and cycles of nature interweave and orchestrate into bundles of expressive rhythms" (Wunderlich 2010: 46). According to her, these rhythms are unique to particular locations and also affect our sense of time in unique ways. The sense of time comes from immediate sensual experiences and involves a meaningful appreciation that defines our relationship with a place. A distinctive temporal experience of place is sensually valued and affectively remembered (ibid.: 45-46), both by the tourism farmers and tour guides as timescape mediators (and according to their narratives, their guests as well).

We will identify and present some distinctive elements of those rural timescapes not in hierarchical order or in a conclusive system, but rather by mapping some ideas of temporality that were identified by the tour guides and tourism farmers. Our following analysis is loosely based on Barbara Adam's above mentioned concept of timescape, where she distinguishes the following nine elements: "time frames (seconds, days, years, lifetimes, eras, epochs); temporality (process, irreversibility, impermanence); tempo (pace, intensity/rate of 
activity); timing (synchronization, Kairos); time point (moment, now, instant, juncture); time patterns (rhythmicity, periodicity, cyclicality); time sequence (series, cause and effect/simultaneity); time extensions (duration, continuity: instant to eternity); time past, present, future (horizons, memory anticipation)" (Adam 2004: 144), focusing on two of them - tempo and time extensions - as these two topics are those that were elicited most prominently from the gathered empirical material.

\section{TEMPO: THE SLOWER PACE OF RURALITY}

A significant aspect of the studied timescapes entails deliberate attempts to 'stop' time, to make the guests visiting Hiiumaa or Võrumaa experience what John Urry (Lash \& Urry 1994: 241) has called "glacial time". This is an attempt to replace instantaneous clock-time with a more inert, slower perception of time (Baerenholdt et al. 2004: 8), an aim that is not limited to the tourism situations only but is connected with "the growing tendency to equate the good life with the slow life" (Shaw 2003: 120; see, for example, Parkins 2004 on "slow food" movement). Rural tourism is certainly one of the fields where peaceful, serene environments for relaxation are created and maintained for the guests. This is a conscious negotiation of the different temporalities which make up the everyday lives of these tour guides and tourism farmers who notice, value and purposely magnify the elements of their everyday lives that seem to suit their guests best, encouraging them to step out of their everyday temporalities.

The changes in the timescape start with the beginning of the journey. Since Hiiumaa is an island, which is not connected to the mainland via a bridge or some other means and in order to get there one has to take the ferry, it is actually possible to determine where the timescape changes and the "glacial time" moves in: the ferry. "The time changes on the ship", as Ester (b. 1942, Hiiumaa) said. Once the guests have boarded the ferry, the awareness of and the immersion in a different timescape can take place on the way to the island, as Ester further explains:

And our own children and relatives who visit us, they say that when they board the ferry, something in the world changes for them. That all this bustle and hurrying stays behind and the situation is totally different. (Ester, b. 1942, Hiiumaa)

The situation in Võrumaa is different: there you cannot actually put your finger on the very liminal situation of the changing temporalities. However, one could say that due to Võrumaa's location in the 'periphery' (from the perspective of 
the capital Tallinn, which is exactly at the other end of the country), the process of getting there (either driving or taking a bus) is in itself time-consuming: at least 3 hours by car and more than 3.5 hours by bus, which in Estonian context is a considerable distance.

"Glacial time" involves an active appreciation of locality; it "can develop in relationship to where one was born or brought up, to one's place of current residence or work, or to where one has visited or even where one might visit corporeally or imaginatively", and it is often opposed to measurable clock-time (Urry 2000b: 159). For the tourism farmers and tour guides interviewed, cities (and the mainland) appeared to be full of instantaneous, 'clock' time, whereas their own timescapes seemed to represent "glacial time" in their narratives - a feeling that the place has persisted and will persist as a distinctive entity even though the world around it might move at a different tempo.

Our clock moves at a different pace from the mainland, we are not in a hurry. You will have to stay really calm, for example, if the ferry doesn't leave on time. (Marju, b. 1951, Hiiumaa)

Our guests have freedom here; they don't have to live by the clock; for example, we don't say that breakfast is served only from 7 to 9 . If they

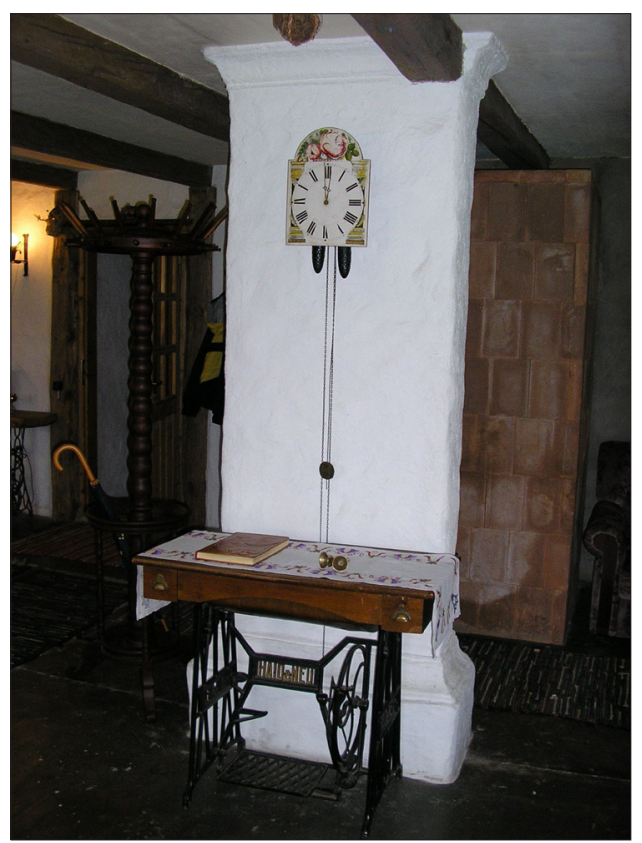

Figure 3. Sometimes time can stand still on a tourism farm. Interior of a farm visited in Võrumaa. Photo by Ester Võsu 2008. 
want breakfast at one o'clock in the afternoon, why not. They are free here. (Juta, b. 1950s, Võrumaa)

The perceived difference of host and guest temporalities can be seen in the following interview excerpt, in which two daughters of the owners of a tourism farm in Võrumaa, Eva and Ene, both in their thirties and both living in Tallinn, but spending as much of their summers at home as possible helping out their parents, discuss the different temporalities of their two homes:

Eva: I think that the people here are a bit different.

Ene: Really calm.

Eva: They are kind of slow and always very helpful.

Ene: How did you put it this morning - meditative? They speak in such calm voices. I went to have a manicure this morning and she [the manicurist] spoke so peacefully to me, it is so different ...

Eva: Calm.

Ene: Calm, peaceful.

Eva: And the other day I went to have my car checked and there was a huge queue, in Tallinn it takes like 15 minutes but he [the mechanic] had lots and lots of time, spoke to me something in the Vorru language and wanted to discuss this and that. Or, for example, when you go to the grocery store. 'Could I have 500 grams of cheese please?' And how the shopkeeper takes this cheese and moves and examines it and how she takes the knife, it can be really irritating at first.

Maarja: Because you're used to things being done more quickly, are they doing things quicker in Tallinn?

Eva: Yes.

Ene: They [the people] themselves even move more quickly in Tallinn.

The situation is similar in Hiiumaa, where informants also see an inherent difference between locals and those who visit the island, the former having a more relaxed attitude towards time everywhere they are, the mainland included:

People from the mainland are nervous in the harbour: why can't I get on the ferry already? The hiidlane waits and [thinks] quietly: 'Oh, so I didn't get on this ferry, it's okay, there will be the next one. I want to go home, but if I cannot, it's okay, I'll just wait for the next one.' (Lili, b. 1956, Hiiumaa)

The tourism farmers strive towards providing their guests with this timescape of a slower quality, one which they see as a counter-scape to the rush and hustle of everyday (usually urban) life. They also tend to prefer (given a choice, of course) the tourists whose principles and worldview they perceive to be more 
similar to theirs, uniting hosts and their guests through different acts of being part of the same environment. "I would like to spend time with people who spend time," said Urmas (b. 1948, Hiiumaa), one of the tour guides interviewed.

The topic that recurs in all the narratives of the tour guides of Hiiumaa is how stressful the short and quick tours are for them. All of them feel and explain that one needs time to experience the island, and most of them expressed the idea that the four-hour tours are something that they really do not want to do if given a choice.

The hardest things are the quick tours. I'm trying to avoid them. But sometimes, when I'm really short of money, I do those four-hour tours as well: rushing to the Kõpu lighthouse and back. But I try to explain to them [the tourists] that it is not possible to really see anything in such a short time, that you can only see a little, I cannot do more within this short period of time, the distances in Hiiumaa are long. They are very surprised, yes, I would say this is folklore or a legend: everyone thinks Hiiumaa is so small and when they come here, then they say: 'Oh, it's 70 kilometres! It is not possible!' (Urmas, b. 1948, Hiiumaa)

The guests are invited and expected to participate in this process of 'slower' living, which can sometimes create a little friction or misunderstandings between the host and the guest if their views on exactly what should be done and enjoyed in this environment, and how, differ slightly.

They [the tour groups] call me up, thinking that they'll have plenty of time, exactly four hours between the two ferries and they think they have enough time in their hands. (Viktor, b. 1960, Hiiumaa)

Both the tourism farmers and tour guides have to negotiate the sometimes different temporalities of their guests. It is especially visible in the case of tour guides, who talk about the topic of time first and foremost in the perceived difference in their desired tempos and the tempos their guests would like to impose upon them: the real amount of time needed for the guided tour to see Hiiumaa. So it often happens that the tour guide just has to make a choice of whether to adjust to the clients' demand and their different perspective of the use of time available to them or not. Several guides stressed that they prefer longer tours that take two days, so that they could show the tourists everything they think is worth seeing on Hiiumaa.

Sometimes [the big tourist groups] are in such a hurry and they have a time schedule that I will have to adjust myself to. (Lili, b. 1956, Hiiumaa). 
For those who just want to come here for four hours and imagine that they can [do anything in that time], I don't do [guided tours] for them. (Viktor, b. 1960, Hiiumaa)

But, as the time passes, the visitors might adjust to the different timescape and start to appreciate it:

When they come from Tallinn on Friday, they are so busy and they can't understand how it is possible that someone is ordering dinner and they have to wait until he's done so that they could check in. Because it is all done at the same front desk. [---] On Saturday, they are already a bit calmer and on Sunday they say: 'It's so peaceful here, I don't want to leave. If only I could stay for one more day!' And they try to organise their work stuff so that they could leave on Monday. (Ester, b. 1942, Hiiumaa)

The tour guides and tourism farmers perceive the different temporal quality of their homes and it is important for them to share this with their guests as well. In the deliberate attempts to slow down time, conscious negotiation of the different timescapes (those of the hosts and those of the guests) occurs.

\section{TIME EXTENSIONS: SILENCE AS A MARKER OF TIME}

The tourism farmers experience temporality by being in touch with the rural environment, with the nature surrounding their farms, listening to its sounds and, just as farmers and tour guides in Hiiumaa, comparing it with other environments (i.e., the city). They dwell in their respective timescapes throughout time, and perceive them through different modes of practice. They discover the temporal, sensual and affective qualities of their timescapes through everyday corporeal and sensory involvements with their lived environments (Wunderlich 2010: 47). The perceived silence or tranquillity of the surroundings provides the tourism farmers with certain timescapes that add a different quality to their lifeworlds, especially when compared to urban settings. In fact, an aural environment perceived as silent can be of great value in rural tourism, and it is often expressed in the wish to keep balance with the nature (Võsu \& Kaaristo 2009: 75).

James and Mills (2005: 13) have noted that "time is not homogeneous, but full of markers on different scales - not only sounding bells, alarms, and ceremonial guns, but changes in the weather, rising and falling levels on the stock market, organic life and death itself". A distinct characteristic of the environment that was often stressed by the interviewed farmers and could be identified as a marker of their timescape is indeed its auditory quality, i.e., the silence. 
Sound is “a phenomenon 'of the moment', an experiential now, appropriate for marking the present but inescapably sequential too, flowing in a rhythmic direction recognized as significant by participants" (James \& Mills 2005: 3, original emphasis). The perceived silence of their timescapes, the expression of duration and continuity (Adam 2004: 144), is an important marker of the living environment, distinguishing it from other environments that are not as desired.

It is really different here, the climate and the nature, the fact that we're an island - they come by ferry, that's something different for them. And for the people - they ride bicycles here. The serenity, the slowness, you don't have to hurry anywhere. (Lili, b. 1970, Hiiumaa)

It must certainly be stressed that 'silence' in the context of these rural timescapes does not mean the nonexistence of sounds, but rather signifies an absence of distinctive urban sounds, such as traffic, etc. (Daugstad 2008: 417-418).

Our ideal guest is a person who loves nature, loves the quiet and peace. They want to come here and be here and switch themselves off from all

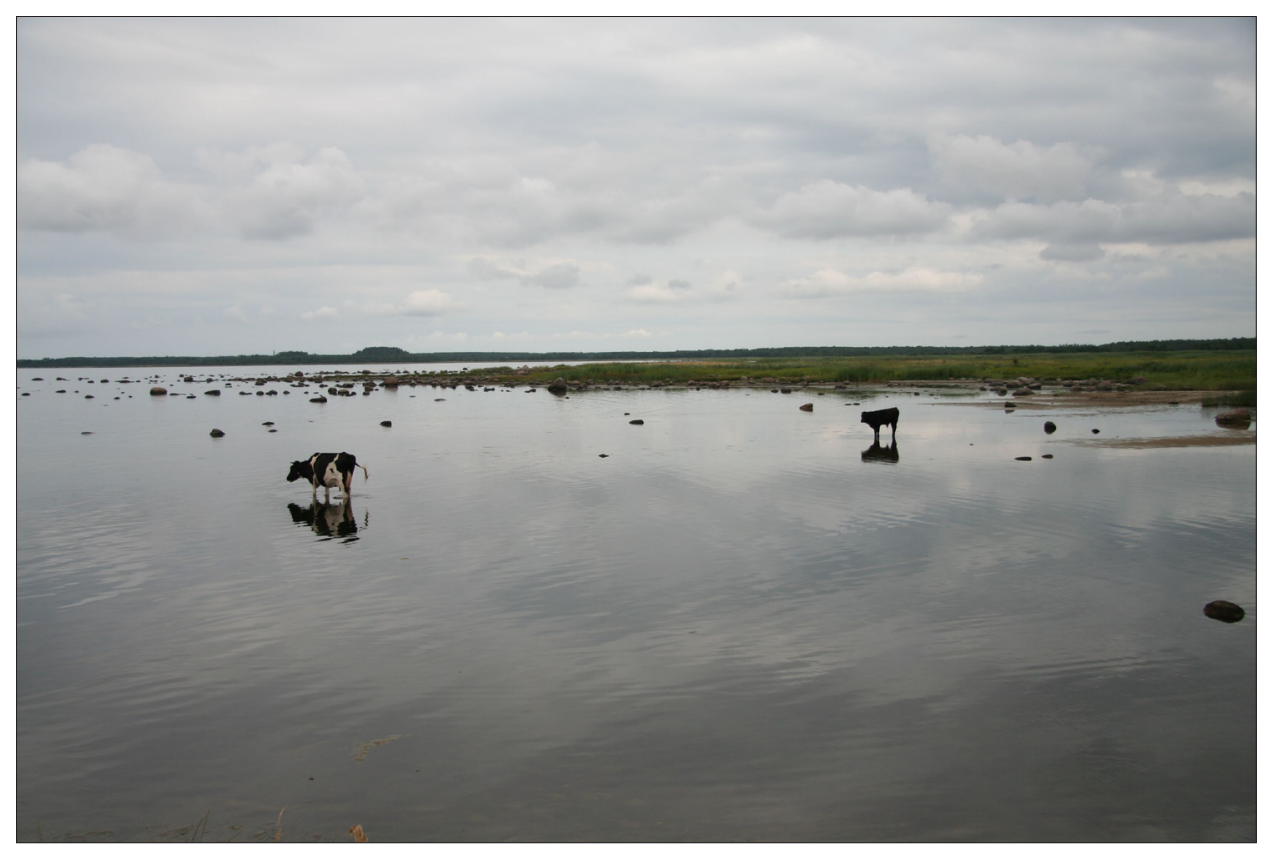

Figure 4. Tourists love nature, quiet and peace. Rural idyll with cows in the sea near Kõrgessaare harbour, Hiiumaa. Photo by Risto Järv 2010. 
this mass communication and the noise and the bustling of the city that usually surrounds them. (Vello, b. 1957, Võrumaa)

Silence is an experience that has visual, aural, social, haptic and temporal aspects. These must be expertly and carefully "harmonized in order to facilitate an experience of silence" (Valtonen \& Veijola 2011: 187) by the tourism farmers. As Paul Rodaway has mentioned, the "sounds of nature seem at times to have been relegated to a background, decorative rather than functional. Inside our buildings and cars, and even public squares and parks, we hide away from natural sounds by playing radios, televisions and compact disc players" (1994: 155). The tourism farmers have noted this as well and try to 'educate' their guests by pushing them towards appreciation of the kind of sounds they think suitable on their farms.

I want to show [on my tourism farm] how the peasant used to live, in harmony with nature. It's about what we are not anymore and how we seek modern amenities everywhere. For example, there's something that we [the tourism farmers] don't particularly like but we have to accept it. When the city people come here, the silence as such and birdsong is killing them. They just must find SkyPlus or Raadio Ring [local radio stations playing pop music] or whatever as long as it makes lots of noise so that they wouldn't hear what's surrounding them. And at midnight they just have to have the fireworks, so that everyone living nearby in the village could hear: we are here and we can do this. But during the last year, I've actually been able to finally change those attitudes. I've arranged fireworks 'a la my farm': at a certain point we light a big bonfire, and that's the fireworks for them. (Aigar, b. 1958, Võrumaa)

Silence is one method of identification in (rural) tourism (often to mark a separation from the noisy, bustling urban environment) and this needs to be carefully arranged and mediated by the tourism farmer who actively tries to 'educate' those who do not seem to share his or her worldviews on what should be enjoyed in this rural environment and how it should be enjoyed. As the perceived 'silence' is one of the timescape markers in rural tourism, this needs to be carefully arranged and mediated by the tourism farmer. Aigar opposes fireworks which, to his liking, make too much noise, so he replaces them with bonfires which make different sounds, are quieter and fit better with his view of his timescape.

Tourism in general is a phenomenon that differentiates the mundane, everyday time from the extraordinary. In the liminoid situation of tourism, the everyday structures that apply in 'normal' situations might not do so anymore and new structures and dispositions are born. Among other things, we can talk about temporality as one of those effects that differentiates normal time from 
the time of tourism. People in the tourism situation, in the rural setting, are introduced to new types of temporality, to a different timescape, and so movement from one timescape to another, although smooth and dynamic, can still be detected in some cases, for example, by passage across the sea on board a ferry from the mainland to Hiiumaa Island.

For many tourism farmers and tour guides the different temporal quality that they perceive in their home is something special that ought to be shared with the tourists. Therefore, the host's personal experience is one of the most important aspects in their creating and conveying this temporal quality to the visitors. The sense of time seems to be place-specific, forming a part of the local identity in the visited rural places. We have taken a closer look at two elements of the timescape: the tempo, slower pace of (rural) life that is experienced by tourism farmers and tour guides in Hiiumaa, and the 'time extensions' - the continuity of the timescapes marked distinctively by its aural quality, i.e., the silence. In the attempts made by the tour guides and tourism farmers to slow down time, guests are offered an opportunity to enjoy a different, slower timescape. This relates well to the tourism farmers, for whom silence (i.e., the absence of urban sounds) is a distinctive temporal marker of their living environment, which they consciously try to mediate to their guests.

\section{NOTES}

1 This research was supported by the European Union through the European Regional Development Fund (Centre of Excellence, CECT) and the target-financed projects Dynamic Perspectives of Identity Politics - Analysis of Dialogue and Conflict (SF0180157s08), Folklore and Folklore Collections in Cultural Changes: Ideologies, Adaptation and Application Context (SF0030180s08) and Folklore and Society: Tradition Memory, Creativity, Applications (SF0180139s08).

The article is based on the conference paper presented at the Finnish anthropology conference, Dynamic Anthropology: Tensions between Theory and Practice, University of Helsinki, Finland, October 5-7, 2011.

2 When speaking about the people living in Võru County, instead of the standard Estonian words võrukesed (people from Võrumaa) and võru keel (Võru dialect), the endonyms in local dialect - võrokesed and võro kiil - are used.

3 Hiidlane - an islander from Hiiumaa.

\section{MANUSCRIPT SOURCES}

Interviews and field notes from Võrumaa, July/September 2008 and June 2010 (in the possession of Maarja Kaaristo and Ester Võsu). 
Interviews and field notes from Hiiumaa by Risto Järv, October 2009, July 2010 and August 2011 (in the Estonian Folklore Archives).

\section{REFERENCES}

Adam, Barbara 1998. Timescapes of Modernity: The Environment and Invisible Hazards. London: Routledge.

Adam, Barbara 2004. Time. Cambridge \& Malden: Polity Press.

Adam, Barbara 2005. Perceptions of Time. In: Tim Ingold (ed.) Companion Encyclopedia of Anthropology. London \& New York: Routledge, pp. 503-526.

Baerenholdt, Jørgen Ole \& Haldrup, Michael \& Larsen, Jonas \& Urry, John 2004. Performing tourist places. Aldershot \& Burlington: Ashgate.

Brubaker, Rogers \& Cooper, Frederick 2000. Beyond "identity". Theory and Society, Vol. 29, No. 1, pp. 1-47.

Buzard, James 1993. The Beaten Track: European Tourism, Literature, and the Ways to „Culture“ 1800-1918. Oxford: Clarendon Press.

Clifford, James 1997. Routes. Travel and Translation in the Late Twentieth Century. Cambridge \& London: Harvard University Press.

D’Cruz, Carolyn 2008. Identity Politics in Deconstruction: Calculating with the Incalculable. Hampshire \& Burlington: Ashgate Publishing Limited.

Daugstad, Karoline 2008. Negotiating Landscape in Rural Tourism. In: Annals of Tourism Research, Vol. 35, No. 2, pp. 402-426, doi:10.1016/j.annals.2007.10.001.

Durkheim, Émile 2001 [1912]. The Elementary Forms of Religious Life. Oxford: Oxford University Press.

Edensor, Tim 2000. Staging Tourism: Tourists as Performers. In: Annals of Tourism Research, Vol. 27, No. 2, pp. 322-344, doi:10.1016/S0160-7383(99)00082-1.

Edensor, Tim 2002. National Identity, Popular Culture and Everyday Life. Oxford \& New York: Berg.

Ehala, Martin 2007. Sustainability of double ethnic identity in majority-minority settings: The case of Estonian and Võro. In: Roger Blokland \& Cornelius Hasselblatt (eds.) Language and Identity in the Finno-Ugric World. Proceedings of the Fourth International Symposium on Finno-Ugric Languages at the University of Groningen, May 17-19, 2006. Maastricht: Shaker, pp. 44-54.

Graburn, Nelson 1989 [1977]. Tourism: The Sacred Journey. In: Valene L. Smith (ed.) Hosts and Guests. The Anthropology of Tourism. Philadelphia: University of Pennsylvania Press.

Graburn, Nelson H. 2001. Secular Ritual: A General Theory of Tourism. In: Valene L. Smith \& Maryann Brent (eds.) Hosts and Guests Revisited. Tourism Issues of the 21st Century. New York \& Sydney \& Tokyo: Cognizant Communication Corporation, pp. 42-52.

Hall, Stuart 2003. Introduction: Who Needs 'Identity'? In: Stuart Hall \& Paul du Gay (eds.) Questions of Cultural Identity. London \& Thousand Oaks \& New Delhi: Sage Publications, pp. 1-17. 
Hiiemäe, Mall 1998. Der estnische Volkskalender. Folklore Fellows' Communications No. 268. Helsinki: Suomalainen Tiedeakatemia (Academia Scientiarum Fennica).

Hodges, Matt 2008. Rethinking time's arrow: Bergson, Deleuze and the anthropology of time. In: Anthropological Theory 8 (4), pp. 399-429, doi:10.1177/1463499608096646.

Hubert, Henri \& Mauss, Marcel 1964 [1898]. Sacrifice: Its Nature and Function. Chicago: University of Chicago Press.

Ingold, Tim 2000. The Perception of the Environment: Essays on Livelihood, Dwelling, and Skill. London: Routledge.

James, Wendy \& Mills, David 2005. Introduction: From Representation to Action in the Flow of Time. In: Wendy James \& David Mills (eds.) The Qualities of Time. Anthropological Approaches. Oxford \& New York: Berg, pp. 1-15.

Järv, Risto 2010. Fairy Tales and Tourist Trips. In: Fabula. Zeitschrift für Erzählforschung / Journal of Folktale Studies / Revue d' Etudes sur le Conte Populaire, Vol. 51 (3-4), pp. 281-294, doi: 10.1515/fabl.2010.026.

Kaasik, Mairi 2008. The Category of Time in Fairy Tales: Searching for Folk Calendar Time in the Estonian Fairy Tale Corpus. In: Journal of Ethnology and Folkloristics, Vol. 2(2), pp. 47-56.

Kindel, Melika 2005. Vaateid kohapärimuse väärtustamisele lähtuvalt Lahemaa turismisituatsioonist. [Evaluation of local tradition: aspects of tourism situation in Lahemaa National Park.] Master's thesis. Manuscript in the of Tartu University Library. http://hdl.handle.net/10062/986.

Koreinik, Kadri 2011. Language ideologies in the contemporary Estonian public discourse: With a focus on South Estonian. Dissertationes Sociologicae Universtatis Tartuensis 5. Tartu: Tartu Ülikooli Kirjastus.

Koreinik, Kadri \& Rahman, Jan (eds.) 2000. A kiilt rahvas kynõlõs... Võrokeste keelest, kommetest, identiteedist [Of the Võro Language, Customs and Identity.] Võro Instituudi toimõtiseq 8. Võro: Võro Instituut.

Lash, Scott \& Urry, John 1994. Economies of Signs and Space. London: Sage.

Leach, Edmund Ronald 1976. Culture \& Communication: The Logic by Which Symbols are Connected: An Introduction to the Use of Structuralist Analysis in Social Anthropology. Cambridge: Cambridge University Press.

Leach, Edmund Ronald 2004. Rethinking Anthropology. Oxford: Berg Publishers.

Lindroos, Karin 2009. Millest räägivad paigad? Paikade identiteet ja sotsiaalsed konstruktsioonid Eesti saartel. [How places communicate? Place identity and social constructions on Estonian islands]. In: Akadeemia, 8, pp. 1499-1514.

Mathieson, Alister \& Wall, Geoffrey 1982. Tourism: economic, physical, and social impacts. New York: Longman.

Munn, Nancy D. 1992. The Cultural Anthropology of Time: A Critical Essay. In: Annual Review of Anthropology, Vol. 21, pp. 93-123, doi:10.1146/annurev. an.21.100192.000521.

Parkins, Wendy 2004. Out of Time: Fast Subjects and Slow Living. In: Time \& Society, Vol. 13, No. 2/3, pp. 363-382, doi:10.1177/0961463X04045662.

Pritchard, Annette 2000. Ways of seeing 'them' and 'us': Tourism representation, race and identity. In: Mike Robinson et al. (eds.) Expressions of Culture, Identity, and Meaning in Tourism. Reflections on International Tourism. Sunderland: Business Education Publishers, pp. 245-262. 
Rabinow, Paul \& Marcus, George E. \& Faubion, James D. \& Rees, Tobias 2008. Designs for an Anthropology of the Contemporary. Durham \& London: Duke University Press.

Roche, Maurice 2001. Citizenship, popular culture and Europe. In: Nick Stevenson (ed.) Culture \& Citizenship. London \& Thousand Oaks \& New Delhi: Sage Publications, pp. 74-98.

Rodaway, Paul 1994. Sensuous Geographies. Body, sense and place. London \& New York: Routledge.

Ruotsala, Helena 2001. Fieldwork at Home: Possibilities and Limitations of Native Research. In: Rethinking Ethnology and Folkloristics. Vanavaravedaja, No. 6, pp. 111-131.

Shaw, Jenny 2003. „Winning territory“. Changing place to change pace. In: Jon May \& Nigel Thrift (eds.) Timespace. Geographies of Temporality. London \& New York: Routledge, pp. 120-132.

Smith, Valene L. 1989 [1977]. Introduction. In: Valene L. Smith (ed.) Hosts and Guests. The Anthropology of Tourism. Philadelphia: University of Pennsylvania Press, pp. 1-17.

Solomos, John 2001. Race, Multi-Culturalism and Difference. In: Nick Stevenson (ed.) Culture \& Citizenship. London \& Thousand Oaks \& New Delhi: Sage Publications, pp. 198-211.

Somers, Margaret 1994. The narrative constitution of identity: A relational and network approach. In: Theory and Society 23, pp. 605-649, doi:10.1007/BF00992905.

Turetzky, Philip 1998. Time. London and New York: Routledge.

Turner, Victor 1967. The Forest of Symbols: Aspects of Ndembu Ritual. New York: Cornell University Press.

Turner, Victor 1982. From Ritual to Theatre: The Human Seriousness of Play. New York: Performing Arts Journal Publications.

Turner, Victor 2008 [1969]. The Ritual Process: Structure and Anti-Structure. Piscataway: Transaction Publishers.

Uljas, Jüri 2001. Social Identity Influences on Environmental Attitudes and Behaviors. In: Trames. A Journal of the Humanities and Social Sciences, Vol. 5 (55/50), No. 3, pp. 255-268.

Uljas, Jüri \& Post, Ruuben 2002 (eds.). Hiiumaa ja hiidlane 1999. Sotsioloogiline uurimus. [Hiiumaa and Its People 1999. Sociological research.] Tallinn: Tallinna Pedagoogikaülikool; Kärdla: Hiiumaa Kaitsealade Administratsioon.

Urry, John 2000a. The Tourist Gaze. London \& Thousand Oakes \& New Delhi \& Singapore: Sage.

Urry, John 2000b. Sociology beyond Societies: Mobilities for the twenty-first century. London: Routledge.

Valtonen, Anu \& Veijola, Soile 2011. Sleep in Tourism. In: Annals of Tourism Research, Vol. 38, No. 1, pp. 175-192, doi:10.1016/j.annals.2010.07.016.

Van Gennep, Arnold 2004 [1909]. The Rites of Passage. London: Routledge.

Võsu, Ester \& Kaaristo, Maarja 2009. An Ecological Approach to Contemporary Rural Identities: The Case of Tourism Farms in South-East Estonia. In: Journal of Ethnology and Folkloristics, Vol. 3(1), pp. 73-94. 
Võsu, Ester \& Kaaristo, Maarja 2010. Sensescapes in farm tourism: staging and performing environments for sensory experiences in the southern Estonian countryside. In: David Picard \& Jeremy Kuster (eds.) Emotion in Motion: The Passions of Tourism, Travel and Movement. Leeds: Centre for Tourism and Cultural Change (CTCC), University of Leeds, CD-ROM.

Wöhler, Karlheinz 2006. Trends towards pure leisure: leisure as ritual performance. In: Paul Ankomah. Time shift, leisure and tourism: Impacts of time allocation on successful products and services. Berlin: Erich Schmidt Verlag.

Wunderlich, Filipa Matos 2010. The Aesthetics of Place-Temporality in Everyday Urban Space: The Case of Fitzroy Square. In: Tim Edensor (ed.) Geographies of Rhythm: Nature, Place, Mobilities and Bodies. Farnham \& Burlington: Ashgate, pp. 45-58. 